Pesq. Vet. Bras. 29(1):94-98, janeiro 2009

\title{
Sheep poisoning by Panicum dichotomiflorum in northeastern Brazil ${ }^{1}$
}

\author{
Franklin Riet-Correa ${ }^{2 *}$, Mitsue Haraguchi ${ }^{3}$, Antônio F. M. Dantas ${ }^{2}$, Rodrigo G. \\ Burakovas $^{3}$, Akihito Yokosuka ${ }^{4}$, Yoshihiro Mimaki ${ }^{4}$, Rosane M.T. Medeiros ${ }^{2}$ \\ and Polyanna F. de Matos ${ }^{5}$
}

\begin{abstract}
Riet-Correa F., Haraguchi M., Dantas A.F., Burakovas R.G., Yokosuka A., Mimaki Y., Medeiros R.M.T. \& Matos P.F. 2009. Sheep poisoning by Panicum dichotomiflorum in northeastern Brazil. Pesquisa Veterinária Brasileira 29(1):94-98. Hospital Veterinário, Centro de Saúde e Tecnologia Rural, Universidades Federal de Campina Grande, Patos, PB 58700-000, Brazil. E-mail: franklin.riet@pq.cnpq.br

Different species of Panicum, including $P$. dichotomiflorum, have been reported as a cause of photosensitization in sheep, horses, cattle and goats. An outbreak of hepatogenous photosensitization occurred in 3 flocks of hair sheep in the Brazilian semiarid region. Eighty one out of 365 sheep were affected and 39 died. The main affected animals were nursing lambs and sheep younger than one year old. Donkeys, goats and cattle grazing in the same pasture were not affected. Clinical signs were edema of the head, followed by dermatitis, mainly in the face, ears, and croup, ocular discharge, corneal opacity with blindness, and redness of the coronary band and hoof. At necropsy of one affected lamb the liver was yellowish. Upon histologic examination scattered necrotic hepatocytes were observed in the liver and focal areas of necrosis of myocytes appeared in the heart. Samples of $P$. dicotomiflorum were analyzed by TLC and those containing saponins were isolated by HPLC using RP-C18 column and eluted with a mixture of $\mathrm{MeOH}$ and $\mathrm{H}_{2} \mathrm{O}$. The isolated compounds were submitted to ${ }^{1} \mathrm{H}$ and ${ }^{13} \mathrm{C}$ NMR spectroscopy. Reactions were positive to furostanol saponins with the same $R_{f}$ of the standard protodioscin (0.21) and methylprotodioscin (0.32). The spectroscopic results indicated a mixture of $(25 R)$ - and (25S)-protodioscin isomers in a proportion of $3: 1$, and methylprotodioscin.
\end{abstract}

INDFEX TERMS: Lithogenic steroidal saponins, Panicum dichotomiflorum, photosensitization, protodioscin.

RESUMO.- [Intoxicação por Panicum dicotomiflorum em ovinos na Região Nordeste.] Diferentes espécies de Panicum, incluindo P. dichotomiflorum, causam fotossen-

\footnotetext{
${ }^{1}$ Received on August 18, 2008.

Accepted for publication on September 29, 2008.

2 Hospital Veterinário, Centro de Saúde e Tecnologia Rural (CSTR), Universidades Federal de Campina Grande (UFCG), Patos, PB 58700000, Brazil. *Corresponding author: franklin.riet@pq.cnpq.br

${ }^{3}$ Centro de Pesquisa e Desenvolvimento de Sanidade Animal, Instituto Biológico de São Paulo, Av. Conselheiro Rodrigues Alves 1252, São Paulo, SP 04014-002, Brazil.

${ }^{4}$ Laboratory of Medicinal Pharmacognosy, School of

Pharmacy, Tokyo University of Pharmacy and Life Sciences, 1432-1 Horinouchi, Hachioji, Tokyo 192-0392, Japan.

${ }^{5}$ Programa Cabra Forte, Secretaria da Agricultura do Estado da Bahia, Av. 4, no 405, Centro Administrativo, Salvador, BA 41750-300,Brazil.
}

sibilização em ovinos, eqüinos, bovinos e caprinos. Um surto de fotossensibilização hepatógena ocorreu em 3 rebanhos de ovinos no município de Casa Nova, Bahia. Oitenta e um de 365 ovinos adoeceram e 39 morreram. Cordeiros lactentes e ovinos de menos de um ano foram mais afetados. Jumentos, cabras e bovinos que permaneciam nas mesmas pastagens não foram afetados. Clinicamente observou-se edema da face, seguido por dermatite, principalmente da face, orelhas e garupa, corrimento ocular, opacidade da córnea com cegueira, e avermelhamento do rodete coronário e casco. Na necropsia de um cordeiro afetado o fígado estava amarelado. Na histologia observouse necrose aleatória de hepatócitos no fígado e áreas focais de necrose de miócitos no miocárdio. Amostras de $P$. dicotomiflorum foram analisadas por cromatografia em ca- 
mada delgada e aquelas contendo saponinas foram isoladas por HPLC utilizando uma coluna RP- $\mathrm{C}_{18}$ com mistura de metanol e água. Os compostos isolados foram submetidos a espectroscopia de ressonância magnética nuclear de hidrogênio $\left(R M N{ }^{1} \mathrm{H}\right)$ e de carbono $\left(R M N{ }^{13} \mathrm{C}\right)$. As reações foram positivas para saponinas furostanólicas com 0 mesmo $R_{f}$ que os padrões de protodioscina $(0,21)$ e metilprotodioscina $(0,32)$. Este resultado e os dados espectroscópicos sugerem a presença, em $P$. dichotomiflorum, de metilprotodioscina e uma mistura de isômeros (25R)- e (25S)- de protodioscina em uma proporção de 3:1.

TERMOS DE INDEXAÇÃO: Saponinas litogênicas esteroidais, Panicum dichotomiflorum, fotossensibilização, protodioscina.

\section{INTRODUCTION}

Different species of Panicum cause hepatogenous photosensitization including $P$. coloratum in sheep (Muchiri et al. 1980, Bridges et al. 1987, Kellerman et al. 2005) and horses (Cornick et al. 1988), P. dichotomiflorum in sheep (Holland et al. 1991, Miles and Wilkins 1991, Munday et al. 1993) and cattle (Holland et al. 1991), P. schinzii in sheep (Button et al. 1987, Miles et al. 1992), and $P$. virgatum in sheep (Puoll et al. 1992, Lee et al. 2001) and horses (Lee et al. 2001). Other species reported as toxic are $P$. maximum (Clare 1952, 1955, Kellerman et al. 2005), P. laevifolium, $P$. effusum, $P$. decompositum, and $P$. miliaceum (Clare 1952, 1955). The toxic substances of Panicum spp are lithogenic steroidal saponins, mainly dichotomin, which after hydrolysis results in the diosgenin and yamogenin sapogenins. In the rumen, diosgenin and yamogenin are metabolized to epismilagenin and episarsasapogenin, which are conjugated with glucuronic acid and then combine with salts of $\mathrm{Ca}^{2+}$ to form crystals in biliar ducts. Crystal formation probably involves the hydrolysis from the saponin followed by reduction of the C-5(6) double bond, epimerization of the 3-b-OH group to $3-\mathrm{a}-\mathrm{OH}$ and finally conjugation with the glucuronic acid (Miles et al. 1991, 1993).

The objective of this paper is to report an outbreak of $P$. dichotomiflorum poisoning in the state of Bahia, northeastern Brazil and the identification of lithogenic steroidal saponins in the plant.

\section{MATERIALS AND METHODS}

An outbreak of hepatogenous photosensitization was studied in 3 flocks of hair sheep in the municipality of Casa Nova, state of Bahia. Observation of epidemiological data and clinical signs were performed during two visits to three farms. One affected lamb was euthanized and necropsied. Samples of liver, kidney, heart, lung, lymph nodes, spleen, thyroid, adrenal, forestomachs, abomasum, small and large intestine, and skeletal muscles were fixed in $10 \%$ buffered formalin, embedded in paraffin and sectioned at 4-6um. The whole central nervous system was also fixed in $10 \%$ buffered formalin and transverse sections taken from the cervical, thoracic and lumbar spinal cord, medulla oblongata, pons, rostral colliculi, thalamus, internal capsule, cortex, cerebellar peduncles and cerebellum were examined histologically. All tissues were stained with hematoxylin and eosin.

Two samples of leaves of Panicum dichotomiflorum collected from different points of the pasture, at the end of November 2005 and start of February 2006, were dried in the shadow, grounded and macerated with $92 \%$ ethanol exhaustively. The ethanolic extract was concentrated under reduced pressure and partitioned between $n$-butanol and water. The $n$-butanol-soluble portion was concentrated to obtain butanolic residue which was passed through a Diaion HP-20 (Mitsubishi-Chemical, Tokyo, Japan) column and successively eluted with water, $20 \%, 40 \%, 60 \%, 80 \%$ and $100 \%$ of methanol. The $60 \%$ methanol fraction after concentrated was submitted on chromatographic column on $60 \mathrm{H}$ silica gel eluted with mixture of chloroform-methanol-water (16:9:2) under media pressure and their sub-fractions were monitored in thin layer chromatography (TLC) using same system of solvents and visualized the spots with Ehrlich reagent. The sub-fractions containing saponins were purified using HPLC on a semipreparative $\mathrm{RP}-\mathrm{C}_{18}$ column and eluted with methanol and water. Next, the obtained pure saponins were submitted spectroscopic analysis of ${ }^{1} \mathrm{H}$ and ${ }^{13} \mathrm{C}$ NMR.

In the same two samples used for saponin analysis the number of Phitomyces chartarum spores were counted by the technique of Di Menna and Bailey (1973).

\section{RESULTS}

The outbreak of hepatogenous photosensitization occurred in 3 flocks of hair sheep during the dry season, in September-November 2005, in the municipality of Casa Nova (40 58' $15^{\prime \prime}$ W $\left.9^{\circ} 43^{\prime \prime} \mathrm{S}\right)$, in the border of the Sobradinho Lake, in the Brazilian semiarid region, in a pasture of mainly Panicum dichotomiflorum. The animals, coming from areas with very low availability of forage due to the dry conditions, were introduced to paddocks in the border of the lake after the water outflow. At the moment of the introduction of the animals there was a good availability of forage of mainly a grass identified as $P$. dichotomiflorum. First cases occurred 15-20 days after the introduction of the flocks in the pasture. During September 2005,155 sheep belonging to two farmers were introduced in the area. The sheep started to show clinical signs 1520 days after the introduction in the area; 65 showed clinical signs and 25 died. One farmer removed the sheep from the paddocks at the end of October, and the other in November $10^{\text {th }}$. The flock removed on November $10^{\text {th }}$ was introduced in the paddock again 20 days later; but two other sheep became sick and the owner removed the flock again. The main affected animals were nursing lambs and sheep younger than one year old. Another farmer introduced 180 sheep in the same area at the start of September; 16 young sheep had photosensitization 15 to 20 days after introduction in the area and 14 of them died. At the end of the outbreak 81 out of 365 hair sheep were affected and 39 died. Donkeys, goats and cattle grazing in the same pasture were not affected. The main pasture in the area was identified as Panicum dichotomiflorum Michx. (=Panicum chloroticum Nees ex Trin, Panicum aquaticum Poir) (Fig.1). When sheep was introduced by the first time, $P$. dichotomiflorum was green and luxurious 

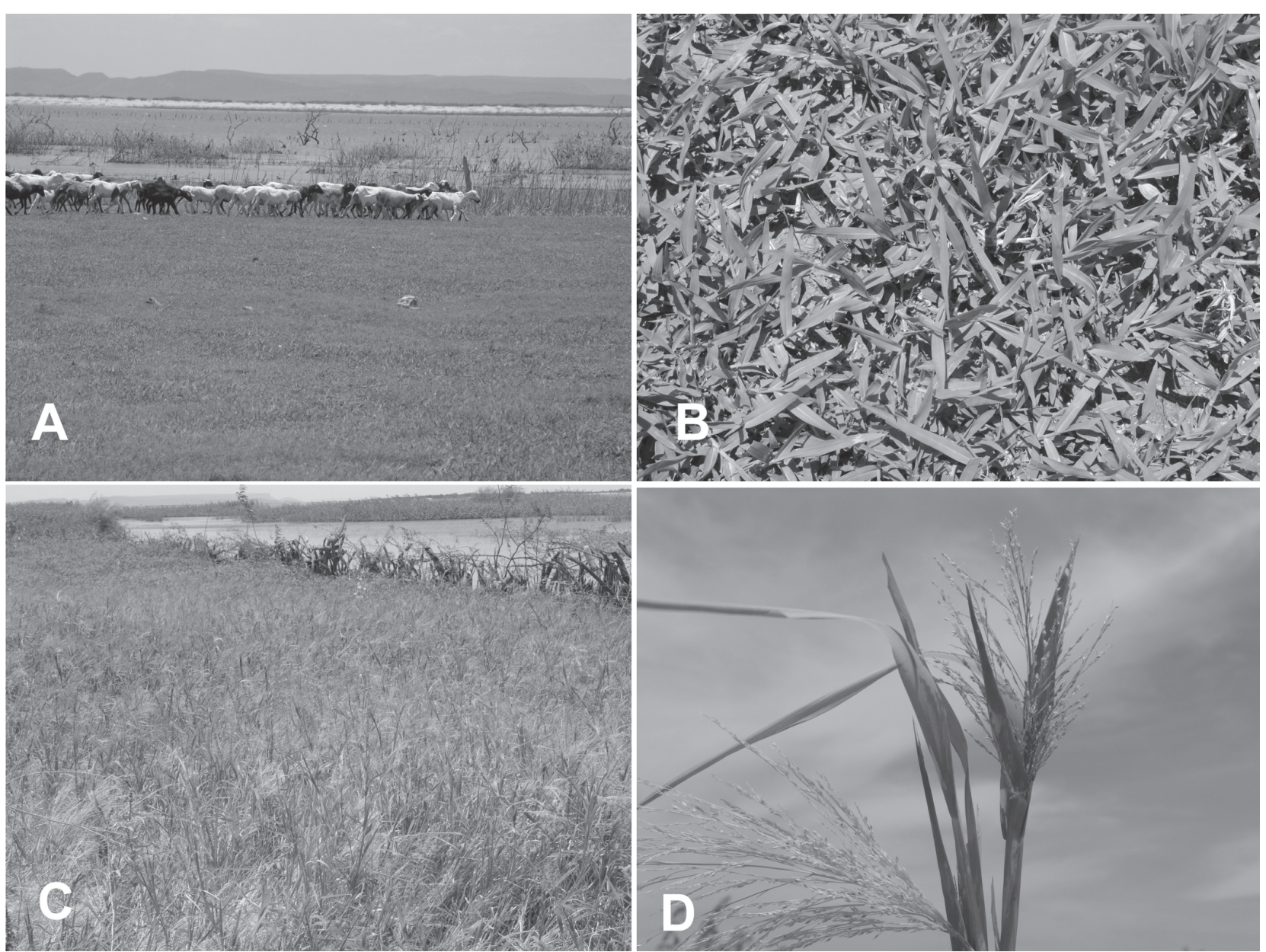

Fig.1. Panicum dichotomiflorum, municipality of Casa Nova, Bahia. $(\mathbf{A}, \mathbf{B})$ The stage of the pasture of $P$. dichtomiflorum after about 90 days grazing is observed. (C,D) $P$. dichotomiflorum, at the same time in an area without grazing.

due to the humidity of the ground. At the end of November $P$. dichotomiflorum was short due to the heavy grazing (Fig.1). At a distance of $300-500 \mathrm{~m}$ from the border of the like the pasture was constituted also by Cynodon dactylon.

The disease affected mainly sheep with white skin. First clinical signs were edema of the head, followed by dermatitis, mainly in the face, ears, and croup, ocular discharge, corneal opacity with blindness, and redness of the coronary band and hoof (Fig.2). The farmers mentioned that some sheep loss the hoof. At the end of November there were 60 sheep in the area. One lamb with lesions of photosensitization (Fig.2A), which was apparently recovering, was euthanized. It had alopecia of the skin of the legs, pinna, and head, and had a red area on abaxial face of the hoof in the region of the perioplum. At necropsy the liver was yellowish. Upon histologic examination of the liver, scattered necrotic hepatocytes were observed mainly in the periportal area (Fig.3A). No crystals were observed in the biliary ducts. Focal areas of necrosis of myocytes which appeared eosinofilic with nuclear picnosis were observed in the heart (Fig.3B). No significant lesions were observed in other organs of the thoracic and abdominal cavities and central nervous system.
The $60 \% \mathrm{EtOH}$ sub-fractions, when submitted to TLC using silica gel plate developed in the system of chloroformmethanol-water (16:9:2) and sprayed with Ehrlich reagent, showed two main spots of magent colour, indicating reaction positive to furostanolic steroidal saponins with the same $R_{f}$ of the standard protodioscin (0.21) and methylprotodioscin (0.32). The spectroscopic data of ${ }^{1} \mathrm{H}$ and ${ }^{13} \mathrm{C}$ NMR of pure saponins after passed on HPLC column indicated a mixture of (25R)- and (25S)-protodioscin isomers in a proportion of 3:1 and methylprotodioscin, when compared with authentic samples (Asami et al. 1991, Kamel et al. 1991). The $P$. dichotomiflorum leaves collected in November and February showed the same saponins indicating no alterations of theirs constituents.

The number of Phitomyces chartarum spores in the pastures was less than 5000 spores by one $\mathrm{g}$ of plant, indicating that the disease was not caused by sporidesmin.

\section{DISCUSSION}

Panicum dicotomiflorum is a highly palatable grass (Holland et al. 1991) which occurs in different Brazilian regions, including the northeastern region, from Piauí 




Fig.2. (A,B) Sheep with photosensitization caused by Panicum dichotomiflorum showing dermatitis on the head. (C) Croup. (D) Perioplum.

State to Bahia State. In southeastern and southern Brazil is a weed found in rice cultures (Lorenzi 2000). The observation of photosensitization in sheep grazing $P$. dicotomiflorum and the presence of protodioscin and methylprotodioscin in the plant suggested that the disease was caused by these saponins contained in the pasture.

This is the first report of protodioscin and methylprotodioscin in $P$. dichotomiflorum. Previous reports found dichotomin in toxic samples of that grass (Miles and Wilkins
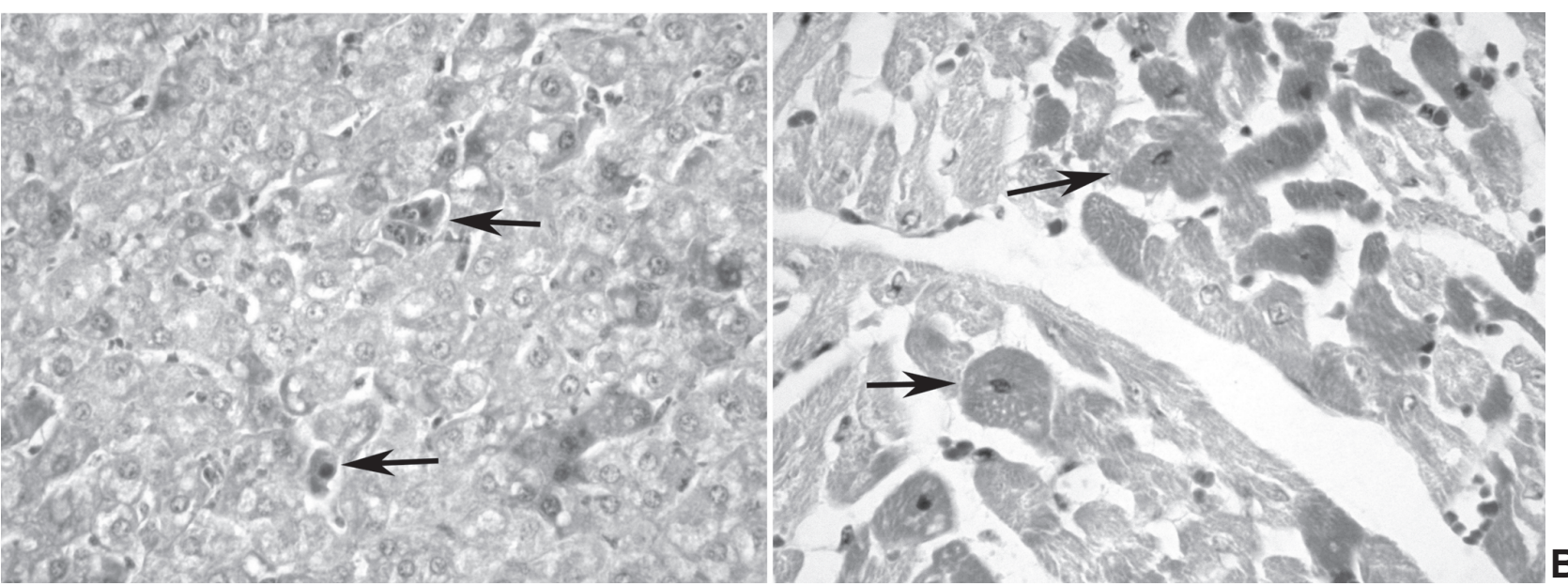

Fig.3. (A) Liver of sheep poisoned by Panicum dichotomiflorum showing necrotic hepatocytes (arrows). (B) Heart of the same lamb showing necrotic myofibers (arrows). 
1991, Munday et al. 1993, Meagher et al. 1996). In Brazil, protodioscin and methylprotodioscin had been identified in Brachiaria decumbens (Brum et al. 2007) and Brachiaria brizantha (Siqueira-Souza et al. 2005). In Brazil, there are reports of photosensitization in irrigated pastures of Panicum maximum (Iveraldo S. Dutra 2006), but using the same techniques reported in this paper in many varieties of $P$. maximum, including $P$. maximum cv. Mombaça and $P$. maximum cv. Massai, collected in farms with historic of colic in horses in the state of Pará, P. maximum cv. Tanzânia with historic of photosensitization in cattle in the state of Goiás, and $P$. maximum cv. Aries and $P$. maximum cv. Aruana collected in the state of São Paulo had low levels of these saponins (Burakovas et al. 2006).

One characteristic of poisoning by plants containing steroidal saponins is the presence of crystals or negative images of them in the biliary system of affected animals (Bridges et al. 1987, Kellerman et al. 2005, Brum et al. 2007), but this alteration is not observed in all intoxicated animals (Bridges et al. 1987). Crystals were also absent in the only lamb necropsied in the outbreaks reported in this paper, which was euthanized when was apparently recovering from the intoxication. The focal necrosis of myocytes observed in the affected lamb was also reported in the poisoning by $P$. coloratum (Bridges et al. 1987) and in Brachiaria decumbens poisoning in sheep (Brum et. al. 2007).

Although $P$. dichotomiflorum is a weed, it is good forage for the region where the intoxication occurred, mainly after the water outflow in the Sobradinho Lake during the dry season when there is considerable shortage of forage in the native vegetation (caatinga). Probably it can be grazed by more resistant species which were not affected in this outbreak (goats, cattle and donkeys) and probably also by adult sheep, which are more resistant than young sheep to the poisoning.

Acknowledgements.- This work was financially supported by Institutos do Milênio, National Council of Scientific and Technologic Development (CNPq), Grant no.420012/2005-2, and by the Programa de Apoio a Núcleos de Excelência (PRONEX), Grant no.001/04, CNPq, FAPESQ, MCT. The authors gratefully acknowledge Professor Odaci F. de Oliveira, Universidade Federal Rural do Semi-Árido, for the botanic identification of Panicum dichotomiflorum.

\section{REFERENCES}

Asami A., Hirai Y. \& Shoji J. 1991. Studies on the constituents of Palmae plants. VI. Steroid saponins and flavonoids of leaves of Phoenix canariensis Hort. ex Chabaud, $P$. humilis Royle var. Hanceana Becc., $P$. dactylifera L. and Licula spinosa Wurmb. Chem. Pharm. Bull. 39:2053-2056.

Bridges C.H., Camp B.J., Livingston C.W. \& Bailey E.M. 1987. Kleigrass (Panicum coloratum L.) poisoning in sheep. Vet. Pathol. 24:525-531.

Brum K.B., Haraguchi M., Lemos R.A.A., Riet-Correa F. \& Fioravante M.C. 2007. Crystal associated cholangiopathy in sheep grazing Brachiaria decumbens containing the saponin protodioscin. Pesq. Vet. Bras. 27:39-42.

Burakovas R.G., Yokosuka A., Mimaki Y., Riet-Correa F., Medeiros R.M.T., Dantas A.F.M., de Matos P.F., Katiki L.M., Veríssimo C.J., Bueno M.S., Brum K.B., Fioravanti M.C.S., Neto J.D.B. \& Haraguchi
M. 2007. Investigations of furostanic saponins in the pasture of Panicum. 30th Annual Meeting of Brazilian Society of Chemistry, Águas de Lindóia city, São Paulo Sate, Brazil. PN-77.

Button C., Paynter D.I., Shiel M.J., Corlson A.R., Paterson P.J. \& Lyford R.L. 1987. Crystal-associated cholangiohepatopathy and photosensitization in lambs. Aust. Vet. J. 64:176-180.

Clare N.T. 1952. Photosensitation in domestic animals. Review, series 3, Commonwealth Bureau of Animal Health, CAB, Farnham, England. $58 p$.

Clare N.T. 1955. Photosensitization in animals. Adv. Vet. Sci. 2:182211.

Cornick J.L., Carter G.K. \& Bridges C.H. 1988. Kleingrass hepatotoxicosis in horses. J. Am. Vet. Med. Assoc. 193:932-935.

Di Menna M.E. \& Bailey J.R. 1973. Pithomyces chartarum spore counts in pasture. N. Z. J. Agric. Res. 16:343-351.

Dutra I.S. 2006. Personal communication (Universidade Estadual Paulista, Araçatuba, SP).

Holland P.T., Miles C.O., Mortimer P.H., Wilkins A.L., Hawkes A.D. \& Smith B.L. 1991. Isolation of the steroidal sapogenin epismilagenin from the bile of sheep affected by Panicum dichotomiflorum toxicosis. J. Agric. Food Chem. 39:1963-1965.

Kamel M.S., Ohtani K., Kurokawa T., Assaf M.H., El-Shanawany M.A, Ali A.A., Kasai R., Ishibashi S. \& Tanaka O. 1991. Studies on Balanites aegyptica fruits, an antidiabetic Egyptian folk medicine. Chem. Pharm. Bull. 39:1229-1233.

Kellerman T.S., Coetzer J.A.W., Naudé T.W. \& Botha C.J. 2005. Plant poisonings and mycotoxycosis. Oxford University Press, Cape Town. 310p.

Lee S.T., Stegelmeier B.L. \& Gardner D.R. 2001. The isolation and identification of steroidal sapogenins in switchgrass. J. Nat. Toxins 10:273-281.

Lorenzi H. 2000. Plantas Daninhas do Brasil. $3^{\text {a }}$ ed., Instituto Plantarum, Nova Odessa, SP. 608p.

Meagher L.P., Wilkins A.L., Miles C.O., Collins R.G. \& Fagliari J.J. 1996. Hepatogenous photosensitization of ruminants by Brachiaria decumbens and Panicum dichotomiflorum in the absence of sporidesmin: lithogenic saponins may be responsible. Vet. Hum. Toxicol. 38:271274

Miles C.O. \& Wilkins A.L. 1991. Identification of a sapogenin glucoronide in the bile of sheep affected by Panicum dichotomiflorum toxicosis. N. Z. Vet. J. 39:150-152.

Miles C.O., Munday S.C., Holland P.T., Lancaster M.J. \& Wilkins A.L. 1992. Further analysis of bile crystals from sheep grazing Panicum schinzii (sweet grass). Aust. Vet. J. 69:34.

Miles C.O., Wilkins A.L., Munday S.C., Flaoyen A., Holland P.T. \& Smith B.L. 1993. Identification of insoluble salts of the $\beta$-D-glucoronides of episarsasapogenin, and epismilagenin in the bile of lambs with alved and examination of Narthecium ossifragum, Tribulus terrestris, and Panicum miliaceum for sapogenins. J. Agric. Food Chem. 41:914917.

Muchiri D.J., Bridges C.H., Ueckert D.N. \& Bailey E.M. 1980. Photosensitization of sheep on kleingrass pasture. J. Am. Vet. Med. Assoc. 177:353-354

Munday S.C., Wilkins A.L., Miles C.O. \& Holland P.T. 1993. Isolation and structure of dichotomim, a furostanol saponin implicated in hepatogenous photosensitization of sheep grazing Panicum dichotomiflorum. J. Agric. Food Chem. 41:267-271.

Puoll J.R., Reid R.L. \& Belesky D.P. 1992. Photosensitization in lambs grazing switchgrass. Agron. J. 84:1077-1080.

Siqueira-Souza V., Sandrini C.N.M., Fioravanti M.C.S. \& Haraguchi M. 2005. Sazonal evaluation of saponins in the pastures of Brachiaria and Andropogon of the Brazilian Middle-West. Arqs Inst. Biológico, São Paulo, 72:43. 